\title{
Italian Organised Crime: Mafia Associations and Criminal Enterprises Letizia Paoli
}

The paper reviews the different forms of organised crime in Italy. To begin with, it focuses on the Sicilian Cosa Nostra and the Calabrian 'Ndrangheta, Italy's two largest and most powerful mafia associations. With their centuries-old histories, articulated structures, sophisticated ritual and symbolic apparatuses and claim to exercise a political dominion, these associations have few parallels in the world of organised crime. In its second section, the paper reviews other groups and networks that are-with varying degrees of justification-also routinely described as organised crime: these range from the Neapolitan Camorra to Apulian organised crime and the so-called new 'foreign mafie' and other criminal entrepreneurs. Whereas the new Italian and foreign players are likely to expand their activities on Italy's illegal markets, the future of Cosa Nostra and the 'Ndrangheta is more uncertain and largely depends on the decisions made by the public administrations.

Keywords: Organised Crime; Italy; Mafia; Cosa Nostra; 'Ndrangheta; Camorra

For almost a century the Italian mafia has been regarded-in the United States and elsewhere-as the prototype of organised crime. In Italy itself, however, the identification between mafia and organised crime was frequently questioned and even denied right up until the mid-1980s. For the social scientists carrying out the first field studies in Sicily between the 1960s and the early 1980s, for example, the mafia was simply a form of behaviour and power. That is, they asserted, there were mafiosi, single individuals, who embodied determined sub-cultural values and exercised specific functions within their communities, but no mafia organisation existed as such [1]. As late as 1983, Pino Arlacchi's successful book, La mafia imprenditrice (Mafia Business), opened with the following statement: 'Social research into the question of the mafia has probably now reached the point where we can say that the mafia, as the term is commonly understood, does not exist' [2]. 
Contrary to what most scholars maintained up to the mid-1980s, judicial inquiries carried out since then have proved that formalised mafia groups do exist. Cosa Nostra in Sicily and the 'Ndrangheta in Calabria are the largest and most stable coalitions and are each composed of about a hundred mafia groups or 'families', as they are called by their members. These are estimated at about three thousand and five thousand males respectively [3].

The first section of this chapter analyses the two above-mentioned mafia consortia, focusing on their internal organisation and culture and singling out their peculiarities vis-à-vis other forms of organised crime. The second section reviews other groups and networks that are-with varying degrees of justification—also routinely described as organised crime. Some final remarks about the future trends of Italian organised crime(s) will follow.

\section{The Organised Crime Core: The Sicilian Cosa Nostra and the Calabrian 'Ndrangheta}

At the turn of the twenty-first century, there are more than five hundred witnesses who can confirm the existence of either the Cosa Nostra or the 'Ndrangheta, because they themselves were members. Though it is not possible to establish clear lines of continuity, recent historical research has demonstrated that antecedents of the contemporary mafia associations existed in the 1880s, if not before. The discovery of new documents in archives and a more objective analysis of the already known papers have demonstrated the presence of mafia groups in Sicily and Calabria since the midnineteenth century. As the historian Paolo Pezzino puts it, if it is true that these sources have to be examined with great prudence, it is also true that the statements on the existence of well structured associations are so many, and finding confirmation in several judicial proceedings, that it would be difficult to deny their reliability' [4].

\section{Secret Brotherhoods}

Cosa Nostra and the 'Ndrangheta possess the distinguishing trait of organisations: independent government bodies that regulate the internal life of each associated family and that are clearly different from the authority structure of their members' biological families. Starting from the 1950s, moreover, superordinate bodies of co-ordination were set up-first in the Cosa Nostra, then in the 'Ndrangheta as well. Composed of the most important family chiefs, they are known as 'commissions' [5]. Although the powers of these collegial bodies are rather limited, the unity of the two confederations cannot be doubted. In fact, it is guaranteed by the sharing of common cultural codes and a single organisational formula. According to a model very frequent in premodern societies, in fact, the Cosa Nostra and the 'Ndrangheta are 'segmentary societies' [6]: that is, they depend on what Emile Durkheim called 'mechanical solidarity' [7], which derives from the replication of corporate and cultural forms. 
Neither the Cosa Nostra nor the 'Ndrangheta can be compared to Max Weber's ideal type of legal-rational bureaucracy, as was suggested by Donald Cressey in the late 1960s with reference to the American La Cosa Nostra [8]. Far from recruiting their staff and organising the latter's work according to the criteria and procedures of modern bureaucracies, mafia groups impose a veritable 'status contract' on their members [9]. With the ritual initiation into a mafia cosca (group), the novice is required to assume a new identity permanently - to become a 'man of honour' —and to subordinate all his previous allegiances to the mafia membership. If necessary, he must be ready to sacrifice even his life for the mafia family.

The 'men of honour' in Sicily and Calabria are obliged to keep secret the composition, the action, and the strategies of their mafia group. In Cosa Nostra, in particular, the duty of silence is absolute. Secrecy constitutes, above all, a defence strategy. Since the unification of Italy in 1861, mafia groups have been at least formally criminalised by the state and, in order to protect themselves from arrest and criminal prosecution for their continuing recourse to violence, they have needed to resort to various degrees of secrecy.

The ceremony of affiliation additionally creates ritual ties of brotherhood among the members of a mafia family: the 'status contract' is simultaneously an act of fraternisation [10]. The new recruits become 'brothers' to all members and share what anthropologists call a regime of generalised reciprocity [11]: this presupposes altruistic behaviour without expecting any short-term reward. As F. Lestingi, chief prosecutor for the king, pointed out in 1884, mafia groups constitute brotherhoods whose 'essential character' lies in 'mutual aid without limits and without measure, and even in crimes.' [12] Only thanks to the trust and solidarity created by fraternisation contracts does it become possible to achieve specific goals and thus satisfy the instrumental needs of the single members.

As secret brotherhoods using violence, Southern Italian mafia associations have remarkable similarities to associations such as the Chinese Triads and the Japanese Yakuza [13]. With their centuries-old histories, articulated structures, and sophisticated ritual and symbolic apparatuses, all these associations-and the American descendant of the Sicilian Cosa Nostra [14] — have few parallels in the world of organised crime. None of the other groups that systematically traffic in illegal commodities have the same degree of complexity and longevity [15].

\section{The Will to Power}

Cosa Nostra and the 'Ndrangheta share another important peculiarity with the Chinese Triads and the Japanese Yakuza. Unlike other contemporary organised crime groups, they do not content themselves with producing and selling illegal goods and services. Though these activities have acquired an increasing relevance over the past 30 years, neither the trade in illegal commodities nor the maximisation of profits has ever been the primary goal of these associations. As a matter of fact, it is hardly possible to single out an encompassing function or goal that characterises the mafia 


\section{L. Paoli}

phenomenon, as has been suggested by the supporters of the 'economistic' paradigm [16], and more recently by Diego Gambetta [17], according to whom the mafia is 'an industry of private protection'. Southern Italian mafia coalitions are multifunctional organisations. In the past hundred years, their members have exploited the strength of mafia bonds to pursue various endeavours and to accomplish the most disparate tasks. As early as 1876 the Tuscan aristocrat Leopoldo Franchetti pointed out the 'extraordinary elasticity' of the associations of malfattori (evildoers): 'the goals multiply, the field of action widens, without the need to multiply the statutes; the association divides for certain goals, remains united for others' [18].

Within this wide range of functions, there is one that usually has been neglected by late-twentieth-century observers: the exercise of a political dominion. The ruling bodies of Cosa Nostra and the 'Ndrangheta claim, above all, an absolute power over their members. They control every aspect of their members' lives, and they aim to exercise a similar power over the communities where their members reside. For a long time, their power had a higher degree of effectiveness and legitimacy than that exercised by the state. In Western Sicily and in Southern Calabria mafia associations successfully policed the general population, settling conflicts, recovering stolen goods, and enforcing property rights. Even today, although most mafia rules are no longer systematically enforced, mafia families exercise a certain 'sovereignty' through a generalised system of extortion. As a state would do, they tax the main productive activities carried out within their territory, which usually corresponds to a village or town, or to a neighbourhood in larger cities. Cosa Nostra and 'Ndrangheta members have not only enjoyed high-level political connections up to the present, but the Italian state and the mafia long shared power in considerable parts of Sicily and Calabria and the power of mafia groups was accepted and even legalised by government representatives [19].

In the second half of the twentieth century, Southern Italy's mafia associations participated in at least three plots organised by right-wing terrorist groups; since the late 1970s Cosa Nostra has assassinated dozens of policemen, magistrates, and politicians. The mafia challenge to state power reached a climax in the early 1990s. In 1992, Cosa Nostra murdered the Palermitan Judges Giovanni Falcone and Paolo Borsellino in two spectacular bomb explosions. In 1993, in an effort to demonstrate the national power of the mafia, a series of bombings occurred-for the first time out of traditional mafia strongholds-in Rome, Florence, and Milan [20].

Despite their power, mafia fraternities have not been able to guarantee themselves a monopoly in any sector of the illegal economy outside of Southern Italy. In the early 1980s, Cosa Nostra families played a pivotal role in the transcontinental heroin trade from Asia to the United States via Sicily. But in the second half of that decade, the Cosa Nostra lost this position after being targeted by law-enforcement investigations and replaced in the US market by a plethora of Mexican, Chinese, and, more recently, Colombian heroin suppliers [21].

Despite the growing relevance of economic activities, 'the mafia has not become a set of criminal enterprises.' [22] Its history as well as its cultural and normative 
apparatus prevent this transformation and today constitute a constraint as much as a resource. By building a strong collective identity, shared cultural codes and norms enhance group cohesion and create trustful relationships among mafia members. The reliance on status and fraternisation contracts, which are non-specific and long-term, produces a high degree of flexibility and makes the multifunctionality of mafia groups possible. The same shared cultural codes and norms also represent, however, a powerful brake on entrepreneurial initiative. The prohibition on exploiting prostitution, for example, which exists in both confederations [23], has blocked the entrance of the Sicilian and Calabrian cosche into what has become a most profitable illicit trade: the smuggling of humans and the exploitation of migrants in the sex industry or the informal economy.

Especially constraining is one of the preconditions for recruitment: only men born either in Sicily or in Calabria or descended from mafia families can be admitted as members. This rule has long prevented Cosa Nostra and 'Ndrangheta families from adding new members with the experience necessary to compete in the black markets for arms, money and gold. Rigid recruitment criteria have also hampered the Q1 geographical expansion of mafia power. Cosa Nostra, for example, prohibits settling families outside of Sicily. This self-imposed rule, which aims to strengthen the cohesion of the mafia consortium, has limited its involvement in the international narcotics trade-currently the largest of the illegal markets. 'Ndrangheta families, thanks to their extensive branches in Northern Italy and abroad, played a larger role in narcotics trafficking in the 1990s, importing large quantities of cocaine and hashish from Latin America and North Africa; today, however, the 'Ndrangheta faces new competition from foreign and Italian traffickers with more direct connections to drugproducing and transit countries.

The 'will to power' of the mafia associations also negatively affects security and business decisions, as a Palermitan prosecutor pointed out in 1992:

The true goal is power. The obscure evil of organisation chiefs is not the thirst for money, but the thirst for power. The most important fugitives could enjoy a luxurious life abroad until the end of their days. Instead they remain in Palermo, hunted, in danger of being caught or being killed by internal dissidents, in order to prevent the loss of their territorial control and not run the risk of being deposed. Marino Mannoia [a former mafia member now co-operating with law-enforcement authorities] once told me: 'Many believe that you enter into Cosa Nostra for money. This is only part of the truth. Do you know why I entered Cosa Nostra? Because before in Palermo I was Mr. Nobody. Afterwards, wherever I went, heads lowered. And to me this is priceless' [24]

As a result, ever since the early 1990s Cosa Nostra and 'Ndrangheta families have extracted a growing percentage of their income from entrepreneurial activities that depend on the exercise of regional political domination. They practise systematic extortion in their communities and, thanks to intimidation and collusion with corrupt politicians, they have struggled to control the market for public works [25]. 


\section{L. Paoli}

Unlike other Western forms of organised crime, the meaning (and danger) of Sicilian and Calabrian mafia associations cannot be limited to their involvement in illegal markets. Their peculiarity lies in their will to exercise political power and their interest in exercising sovereign control over the people in their communities.

\section{Other forms of Organised Crime in Italy}

In addition to the Sicilian Cosa Nostra and the Calabrian 'Ndrangheta, two other clusters of crime groups are usually referred to as organised crime in Italy: 1) the 'galaxy' of mafia-like and gangster-like groupings in Campania, collectively known as Camorra and 2) the multiplicity of criminal groups, gangs and white-collar criminal networks operating in Apulia.

\section{The Camorra}

The Camorra consists in a variety of independent criminal groups and gangs. Some of them are well-established family businesses that, as much as Sicilian and Calabrian mafia groups, claim to exercise a political dominion over their neighbourhoods and villages and systematically infiltrate local government institutions, at some point enjoying the protection of high-level national politicians as well. Other Camorra groups are less lasting formations that have developed around a charismatic chief, usually a successful gangster. Finally, there are also loose gangs of juvenile and/or adult offenders, which-according to police sources-rather belong to the sphere of common crime than to that of organised crime [26].

To strengthen their legitimacy and cohesion, many of the above groups frequently resort to the symbols and rituals of the nineteenth-century Camorra. This was an organisation sharing several cultural and organisational similarities with its Sicilian and Calabrian counterparts, though it distinguished itself by its concentration in the city of Naples and its plebeian background. Unlike Cosa Nostra and the 'Ndrangheta, however, the contemporary Campanian underworld does not directly derive from its nineteenth-century forerunner. As Isaia Sales puts it, if Camorra means a criminal organisation that ruled over Naples' popular and plebeian strata, we can safely say that it started and ended in the nineteenth century' [27].

The Camorra was 'born again' in the 1960s, thanks to the expansion of smuggling in tobacco and later, in drugs. In the 1980s, several Camorra groups and short-lasting coalitions of groups (above all, the Nuova Camorra Organizzata and the Nuova Famiglia) then gained great wealth and power with the appropriation of the public money flows invested in Campania after the earthquake of 1980 [28]. Despite their extensive infiltration of the legitimate economy and the public administration, however, contemporary Camorra groups have not succeeded in establishing stable co-ordination mechanisms such as those of the nineteenth-century Camorra or of the Sicilian and Calabrian mafia associations. As a result, Campania has had the highest rate of murders and violent crime in all of Italy for more than a decade. 
The heterogeneity and anarchy of the Campanian underworld are also proved by the great variety of entrepreneurial activities the local crime groups are involved in. The most powerful Camorra clans are still able to condition the local legitimate economy, despite the devastating investigations conducted by law enforcement agencies in the 1990s. The smaller groups and gangs engage in all sorts of illegal activities-from extortion to fraud, from drug trafficking and dealing to loansharking, from counterfeiting to the exploitation of prostitution-and are ready to resort to violence whenever they see their 'turf' and activities being threatened [29].

\section{So-called Apulian Organised Crime and other Groups}

The development of Apulian 'organised crime' goes back to the 1970s, when the region became Italy's major import point for smuggled cigarettes and was 'colonised' by neighbouring mafia and Camorra groups. In the following years, indigenous crime groups and gangs sprang up in different parts of Apulia. The most successful of these collective actors was long the Sacra Corona Unita ('United Holy Crown'), a consortium of about ten to fifteen criminal groups and gangs from Southern Apulia, which was founded in 1983 [30]. Contrary to the accounts of the media, the Sacra Corona Unita never controlled the whole of Apulian organised crime; despite its imitation of the 'Ndrangheta's structure and rituals, its cohesion and stability have always been much lower. Today, after the defection of some of its leaders and the arrest of most of its members, the Sacra Corona Unita no longer exists as a single viable organisation [31].

Notwithstanding the decline of the Sacra Corona Unita, illegal business activities go on. Up to few years ago tobacco smuggling was the main source of revenue for most Apulian criminal enterprises. Since the early 1990s these have diversified their investments, exploiting their strategic geographical position to smuggle drugs and migrants from the close Balkan countries. In the last few years, as the improved cooperation of Italian and Albanian police forces resulted in an intensified repression of tobacco smuggling, Apulian crime groups have also started to engage in extortion, usury, robberies and counterfeiting, to compensate for their loss of revenues.

The members of Italy's four major domestic crime 'clusters' are the privileged addressees of charges pursuant to Article 416bis of the Italian penal code, that defines the offence of 'membership in a mafia-type delinquent association' (associazione a delinquere di stampo mafioso) and represents the most stringent legal translation of the concept of organised crime in the Italian legal system [32].

A few other criminal coalitions and gangs located in Eastern and Southern Sicily and in Northern Calabria, such as the Stidda in the Agrigento and Caltanissetta provinces or the Laudani, Cursoti and Pillera-Cappello in Catania, are also occasionally referred to as organised crime or mafia. Their internal cohesion and political and economic resources are much lower than those of Cosa Nostra or 


\section{L. Paoli}

'Ndrangheta families, though Sicilian groups have from time to time been able to threaten the supremacy of the local Cosa Nostra families due to their larger number of members and their readiness to use violence [33].

\section{The New 'Foreign Mafie' and Inconspicuous Players}

The expressions 'organised crime' and 'mafie' are also increasingly used to refer to foreign criminals operating in Italy. For example, the last bi-annual reports on the activities of the Direzione Investigativa Antimafia, a police body specialising in the fight against organised crime, all contain a chapter devoted to 'criminalità organizzate straniere' (foreign organised criminalities) [34].

As a matter of fact, Italy has over the past 20 years undergone a process of internationalisation and ethnicisation of its illegal markets. This trend, which started in other Western European countries in the 1950s, took place very rapidly in Italy from the mid-1980s on, when Italy, too, became the destination of considerable migration flows. All over Europe, the internationalisation of illegal markets was strongly accelerated in the 1990s by the European integration process and the abolition of border controls as well as by the radical transformations that occurred in what was once called the 'Second World': the former Soviet Union and Eastern Europe. Paradoxically, in Italy the internationalisation of illegal markets was also favoured by the successes of the law enforcement forces, that in the 1990s dismantled the most consolidated branches of mafia groups in the Centre and North of Italy. The empty spaces, once controlled by the powerful clans of the Calabrian 'Ndrangheta and the Sicilian mafia, are today occupied by various groups and gangs of different ethnic origin and make-up [35].

As a result, today in Milan as in Rome, Frankfurt, London or Amsterdam, illicit goods and services are offered and exchanged by a multiethnic variety of people. Next to mafiosi and local criminals, one finds illicit entrepreneurs coming from all parts of the world. A few of these 'ethnic' criminals - in particular the Chinese ones-tend to exercise a sort of political power within their own communities [36]—much like the Sicilian and Calabrian mafiosi in their strongholds. However, most of the foreign criminal groups and actors active in Italy cannot claim to exercise a political authority. They merely content themselves with making fast money by trading in illicit commodities and/or reinvesting dirty money from their home countries in the European Union and, specifically, in Italy.

Their internal composition is also much different from that of Southern Italian mafia families. Foreign crime groups and gangs active in Italy hardly have the longevity and organisational complexity of Southern Italian mafia associations. Some of them are family businesses or organisations cemented by profit-making or by shared revolutionary or ideological goals; many more are loose gangs, founded on ties of friendship and locality. These are usually small, ephemeral enterprises that can be most correctly described as 'crews': loose associations of people, which form, split, and come together again as opportunity arises. In crews, positions and tasks are usually 
interchangeable and exclusivity is not required: indeed, many crew members frequently have overlapping roles in other criminal enterprises [37].

Illegal market groups and crews are by no means composed exclusively of foreigners. At all levels of Italy's illegal markets we also find people belonging to the mainstream population with no previous underworld connections. It is enough to say that two of the largest cocaine importers in the late 1990s were neither mafia members nor foreigners, but Italians who merely belonged to the sphere of white-collar crime. The first was a Milanese, who invested money earned from loansharking in the drug business and was able to import 600-800 kilograms of cocaine directly from Colombia each time. The second was a former bank manager from Naples, who was responsible for several 400-700-kilogram cocaine shippings. Both of them supplied a plurality of wholesale traffickers, including members of Southern Italian mafia groups, who resided in several parts of the country [38].

As such, the 'new' illegal market players fit better into the 'entrepreneurial' definitions of organised crime that are en vogue in Northern and Central Europe than into the mafia-centered understanding of organised crime that is widespread in Italy [39]. Despite the lack of empirical proof, however, foreign illicit entrepreneurs are all too frequently labelled as mafia and are believed to be organised in the same way as Cosa Nostra and the 'Ndrangheta. Sooner or later-in Italy and elsewhere-we will have to discuss seriously these assumptions and the opportunity of employing the instruments developed in anti-mafia campaigns in the fight against this 'other' form of organised crime, which-if we take the Italian understanding of the concept as a parameter-is not as organised as it is very often made out to be.

\section{Future Trends}

Whereas the new Italian and foreign players are likely to expand their activities on Italy's illegal markets, the future of the Sicilian Cosa Nostra and the Calabrian 'Ndrangheta is more uncertain.

Far from expanding outwards, Cosa Nostra groups and, to a lesser extent, even those of the 'Ndrangheta have in the last fifteen years receded into their territories, avoiding international competition. Today they obtain a growing and preponderant quota of their revenues by manipulating the tendering process of public works and imposing generalised extortive regimes on all the economic enterprises of their areas. Instead of creating stable 'enterprise syndicates' [40] capable of operating on international illegal markets, both Sicilian and Calabrian mafia families tend to fuse entrepreneurial action with the action typical of 'power syndicates' and thus to concentrate on those profit-making activities that are more directly advantaged by the control of a territory and collusion with politicians and government officials. Though the relationship with the latter has lost its rooting in a common weltanschauung and is accepted by shrinking portions of public opinion, Cosa Nostra and 'Ndrangheta cosche have become even more dependent on the decisions made by public, local and central 


\section{L. Paoli}

administrations. These administrators are thus today largely arbiters of both the judicial and the economic-financial lots of mafia coalitions.

It is, above all, to condition the outcome of the pending trials, to amend heavy firstdegree sentences in appeal trials and to improve the detention conditions of their imprisoned members that the Cosa Nostra and 'Ndrangheta families need politicians and public officials to comply with them. The manipulation of state decision-making processes, however, does not merely have judicial goals, as mafia families count on their ramifications in the state administration to improve their financial lot as well.

All Sicilian and Calabrian mafia families place their hopes for economic recovery in the gaining of public contracts, which have just started to be distributed once more, especially in the South, after the sharp drop following the Tangentopoli ('Bribesville', initially an allusion to Milan) inquiries [41]. Between 2000 and 2006, Sicily and Calabria will respectively dispose of $€ 9,000,000,000$ and $€ 5,000,000,000$ coming from the EU funds of Agenda 2000. Apparently, the cosche intend to acquire-directly and through front-men-a substantial portion of these funds and of the sums that are being distributed by the central government and the local administrations. Unaware of being wiretapped, a Sicilian 'man of honour' recently stated: 'They say we should not make any fuss, they recommend that we all avoid making noise and attracting attention, because we have to get all this Agenda 2000...' [42]

What is at stake was clearly singled out in the report on the DIA's activities in the second half of 2000: 'if Cosa Nostra relies on dragging the public funds foreseen for large-scale construction works in order to recover definitively, preventing it from implementing this project could plunge it into one of the most serious crises it has ever known' [43]. Unfortunately, this awareness does seem to shared by the cabinet headed by Silvio Berlusconi, set up in June 2001. As the Minister for Public Work, Pietro Lunardi, officially stated a few months afterwards, while talking about the huge public investments foreseen for the construction of a bridge over the Messina straits, 'in Southern Italy there is the mafia and we need to come to terms with it' [44]. Incompetence or mafia collusion? It is hard to say. There can be no doubt, however, about the following point: even more than in the past, mafia associations' survival now seems to depend on how their relationships with politics and different sectors of the public administration are set up in the future.

If mafia groups do not receive the political support they desperately need, in the middle-term Italy might end up having the same type of organised crime that is widespread in the rest of Europe: namely, a myriad of criminal enterprises selling prohibited commodities with no ambitions to exercise a political power of any sort.

\section{Notes}

[1] See Hess, Mafia and Mafiosi: the Structure of Power; Blok, The Mafia of a Sicilian Village, 1860-1960: a Study of Violent Peasant Entrepreneurs; Schneider, Culture and Political Economy in Western Sicily. 
[2] Arlacchi, Mafia Business: the Mafia Ethic and the Spirit of Capitalism. See also Catanzaro, Men of Respect. A Social History of the Sicilian Mafia.

[3] Paoli, Mafia Brotherhoods: Organized Crime, Italian Style.

[4] Pezzino, 'Stato violenza società. Nascita e sviluppo del paradigma mafioso'. For a similar opinion, see also Lupo, 'Il tenebroso sodalizio'. Un rapporto sulla mafia palermitana di fine Ottocento.

[5] Paoli, Mafia Brotherhoods, 40-64.

[6] Smith, Corporations and Society, 98.

[7] Durkheim, The Division of Labor in Society, 176-7.

[8] Cressey, Theft of the Nation.

[9] Weber, Economy and Society, 72.

[10] Ibid.

[11] Sahlins, Stone Age Economics, 193-200.

[12] Lestingi, 'L'associazione della Fratellanza nella provincia di Girgenti', 453.

[13] Murray, The Origins of the Tiandihui. The Chinese Triads in Legend and History; Kaplan, Yakuza: Japan's Criminal Underworld.

[14] Paoli, Mafia Brotherhoods, 3-12.

[15] Paoli, 'The Paradoxes of Organised Crime'.

[16] Catanzaro, Men of Respect; Santino \& La Fiura, L'impresa mafiosa. all'Italia agli Stati Uniti.

[17] Gambetta, The Sicilian Mafia. The Business of Private Protection.

[18] Franchetti, Condizioni politiche ed amministrative della Sicilia, 100.

[19] Paoli, Mafia Brotherhoods chapters 4 and 5.

[20] Stille, Excellent Cadavers: The Mafia and the Death of the First Italian Republic.

[21] Paoli, Mafia Brotherhoods, 215-7.

[22] Becchi, \& Turvani, Proibito? Il mercato mondiale della droga, 156.

[23] Falcone with Padovani, Men of Honour: The Truth about the Mafia, 115.

[24] Scarpinato, 'Mafia e politica', in Mafia. Anatomia di un regime, 45.

[25] Paoli, Mafia Brotherhoods, 218-9.

[26] Ministero dell'Interno, Rapporto sul fenomeno della criminalità organizzata (anno 2000), 60-5.

[27] Sales, 'Camorra', 468.

[28] Sales, La camorra. Le camorre; Monzini, Gruppi criminali a Napoli e a Marisglia. La delinquenza organizzata nella storia delle due città (1820-1990).

[29] Ministero dell'Interno, Rapporto, 60-75.

[30] Massari, La Sacra corona unita: potere e segreto.

[31] Ministero dell'Interno, Relazione semestrale sull'attività svolta e i risultati conseguiti dalla Direzione Investigativa Antimafia nel primo semestre del 2002, 57-64.

[32] Ingroia, L'associazione di tipo mafioso.

[33] Ministero dell'Interno, Rapporto 2001 and Relazione semestrale 2002.

[34] See, for example, Ministero dell'Interno, Relazione semestrale sull'attività svolta e i risultati conseguiti dalla Direzione Investigativa Antimafia nel secondo semestre del 2000 and Relazione semestrale, 2002.

[35] Paoli, Pilot Project to Describe and Analyse Local Drug Markets-First Phase Final Report: Illegal Drug Markets in Frankfurt and Milan, 110-15.

[36] See Suchan, 'La criminalità oranizzata cinese in Toscana'.

[37] Paoli, 'Flexible Hierarchies and Dynamic Disorder: the Drug Distribution System in Frankfurt and Milan'.

[38] Paoli, Pilot Project, 110-15.

[39] See Paoli, 'The Paradoxes of ...' cit., and Fijnaut \& Paoli (eds), Organised Crime.

[40] Block, East Side—West Side: Organizing Crime in New York.

[41] Barbacetto et al., Mani Pulite: La vera storia. 
FGLC 60103-26/10/2004-124362

\section{L. Paoli}

[42] La Repubblica, 6 February 2001, 15; see also Consiglio Superiore della Magistratura, Verifica della evoluzione delle forme organizzativo-dirigenziali di Cosa Nostra al fine di un'eventuale elaborazione di proposte per attuare strategie di contrasto. Risoluzione approvata dall'Assemblea Plenaria nella seduta antimeridiana del 7 giugno 2001, 13-15.

[43] Ministero dell'Interno, Relazione 2001, 16.

[44] La Repubblica, 23 August 2001, 2.

\section{References}

Arlacchi, P. (1988) Mafia Business: the Mafia Ethic and the Spirit of Capitalism, Oxford University Press, p. 3.

Barbacetto, G., Gomez, P. \& Travaglio, M. (2002) Mani Pulite: la vera storia, Editori Riuniti. Becchi, A. \& Turvani, M. (1993) Proibito? Il mercato mondiale della droga, Donzelli, p. 156.

Block, A. A. (1983) East Side-West Side: Organizing Crime in New York, Transaction Books.

Blok, A. (1988) The Mafia of a Sicilian Village, 1860-1960: a Study of Violent Peasant Entrepreneurs, Polity Press.

Catanzaro, R. (1992) Men of Respect. A Social History of the Sicilian Mafia, The Free Press.

Cressey, D. (1969) Theft of the Nation, Harper and Row.

Durkheim, E. (1964) The Division of Labor in Society, The Free Press, pp. 176-177.

Falcone, G. \& Padovani, M. (1993) Men of Honour: The Truth about the Mafia, Warner, p. 115.

Franchetti, L. (1993) Condizioni politiche ed amministrative della Sicilia, Donzelli, p. 100.

Gambetta, D. (1993) The Sicilian Mafia. The Business of Private Protection, Harvard University Press.

Hess, H. (1973) Mafia and Mafiosi: the Structure of Power, Saxon House.

Ingroia, A. (1993) L'associazione di tipo mafioso, Giuffré.

Kaplan, D. (2003) Yakuza: Japan's Criminal Underworld, University of California Press.

Lestingi, F. (1884) 'Lassociazione della Fratellanza nella provincia di Girgenti', Archivio di Psichiatria, Antropologia Criminale e Scienze Penali, vol. 5, p. 453.

Lupo, S. (1988) “"Il tenebroso sodalizio", Un rapporto sulla mafia palermitana di fine Ottocento', Studi storici, vol. 29, no. 2.

Massari, M., La Sacra corona unita: potere e segreto (Laterza, 1998).

Ministero dell'Interno, Rapporto sul fenomeno della criminalità organizzata (anno 2000) (Camera dei Deputati, 2001), 60-5.

Ministero dell'Interno, Relazione semestrale sull'attività svolta e $i$ risultati conseguiti dalla Direzione Investigativa Antimafia nel secondo semestre del 2000 (2001) and Relazione semestrale, 2002.

Ministero dell'Interno, Relazione semestrale sull'attività svolta e i risultati conseguiti dalla Direzione Investigativa Antimafia nel primo semestre del 2002 (2002), 57-64.

Monzini, P. (1999) Gruppi criminali a Napoli e a Marisglia. la delinquenza organizzata nella storia delle due città (1820-1990) (Meridiana Libri).

Murray, D. H. (1994) The Origins of the Tiandihui. The Chinese Triads in Legend and History, Stanford University Press.

Paoli, L. (2000) Pilot Project to Describe and Analyse Local Drug Markets—First Phase Final Report: Illegal Drug Markets in Frankfurt and Milan, EMCDDA, pp. 110-115.

Paoli, L. (2002) 'Flexible hierarchies and dynamic disorder: the drug distribution system in frankfurt and Milan', Drugs: Education, Prevention and Policy, vol. 9, no. 2.

Paoli, L. (2002) 'The paradoxes of organised crime', Crime, Law, and Social Change, vol. 37, no. 1.

Paoli, L. (2003) Mafia Brotherhoods: Organized Crime, Italian Style, Oxford University Press, pp. 24-32.

Pezzino, P. (1987) 'Stato violenza società. Nascita e sviluppo del paradigma mafioso', in la Sicilia, eds M. Aymard \& G. Giarrizzo, Giulio Einaudi Editore, p. 954. 
FGLC $60103-26 / 10 / 2004-124362$

Mafia associations and criminal enterprises 31

la Repubblica, 6 February 2001 p. 15; see also Consiglio Superiore della Magistratura, Verifica della evoluzione delle forme organizzativo-dirigenziali di Cosa Nostra al fine di un'eventuale elaborazione di proposte per attuare strategie di contrasto. Risoluzione approvata dall'Assemblea Plenaria nella seduta antimeridiana del 7 giugno 2001. Relatore: G. Natoli (2001), 13-15.

la Repubblica, 23 August 2001, 2.

Sahlins, M. D. (1972) Stone Age Economics, Aldine Atherton, pp. 193-200.

Sales, I. (1993) la camorra. le camorre, Editori Riuniti.

Sales, I. (2001) 'Camorra', Appendice 2000, Treccani, p. 468.

Santino, U. \& la Fiura, G. (1990) L'impresa mafiosa. all'Italia agli Stati Uniti, Angeli.

Scarpinato, R. (1992) 'Mafia e politica', Mafia. Anatomia di un regime, Librerie Associate, p. 45.

Schneider, J. \& P. (1976) Culture and Political Economy in Western Sicily, Academic Press.

Smith, M. G. (1974) Corporations and Society, Duckworth, p. 98.

Stille, A. (1995) Excellent Cadavers: The Mafia and the Death of the First Italian Republic, Jonathan Cape.

Suchan, P. (2001) 'la criminalità oranizzata cinese in Toscana', in Mafie nostre, mafie loro. Criminalità organizzata italiana e straniera al Centro Nord, eds M. Massari \& S. Becucci, Comunità.

Weber, M. (1978) in Economy and Society, eds G. Roth \& C. Wittich, University of California Press, p. 72 [1922]. 


\section{Author Query Sheet}

\begin{tabular}{|l|l|}
\hline \multicolumn{2}{|c|}{ Manuscript Information } \\
\hline $\begin{array}{l}\text { Journal } \\
\text { Acronym }\end{array}$ & fGLC \\
\hline $\begin{array}{l}\text { Volume and } \\
\text { issue }\end{array}$ & Vol.1 No.1 \\
\hline Author name & Letizia Paoli \\
\hline $\begin{array}{l}\text { Manuscript } \\
\text { No. (if } \\
\text { applicable) }\end{array}$ & \\
\hline
\end{tabular}

AUTHOR: The following queries have arisen during the editing of your manuscript. Please answer the queries by marking necessary corrections at the appropriate positions on the PROOFS. Do not answer the queries on the query sheet itself. Please also return a copy of the query sheet with your corrected proofs. 
AQ1 I'm unsure of the sense of the sentence: 'Cosa Nostra, for example, prohibits settling families outside of Sicily.'

Does this mean that no Cosa Nostra member is allowed to move away from Sicily? If so, the meaning would be clearer if the sentence were rephrased as follows: 'Cosa Nostra, for example, prohibits families settling outside of Sicily.' 